\title{
Residual ACtivity of Herbicides Used in Soybean Agriculture ON GRAIN SORGHUM CROP SUCCESSION ${ }^{1}$
}

\author{
Atividade Residual de Herbicidas Utilizados na Cultura da Soja sobre o Sorgo Granífero \\ Cultivado em Sucessão
}
DAN, H.A. ${ }^{2}$, DAN, L.G.M. ${ }^{3}$, BARROSO, A.L.L. ${ }^{4}$, PROCÓPIO, S.O. ${ }^{5}$, OLIVEIRA JR., R.S. ${ }^{6}$, SILVA, A.G. ${ }^{3}$, LIMA, M.D.B. ${ }^{4}$ and FELDKIRCHER, C. ${ }^{7}$

\begin{abstract}
The sorghum is a kind of prominence before the cultures used in succession in the Brazil. However, little information concerning the effects of residual activity of herbicides on the crop in this region are known. The objective of this study was to evaluate the residual activity of herbicides used in weed management in soybeans as well as check their effects on grain sorghum grown in succession. For the field experiment, we used a randomized block design with four replications. Eight herbicide treatments were evaluated: imazaquin $\left(0,161 \mathrm{~kg} \mathrm{ha}^{-1}\right)$, diclosulam $\left(0,035 \mathrm{~kg} \mathrm{ha}^{-1}\right)$, sulfentrazone $\left(0,600 \mathrm{~kg} \mathrm{ha}^{-1}\right)$ and flumioxazin $\left(0,05 \mathrm{~kg} \mathrm{ha}^{-1}\right)$ in applications made before emergency and chlorimuron-ethyl $\left(0,015 \mathrm{~kg} \mathrm{ha}^{-1}\right)$, imazethapyr $\left(0,060 \mathrm{~kg} \mathrm{ha}^{-1}\right)$, imazethapyr $\left(0,100 \mathrm{~kg} \mathrm{ha}^{-1}\right)$ and fomesafen $\left(0,250 \mathrm{~kg} \mathrm{ha}^{-1}\right)$ applied post-emergence soybean (V3 stadium, $18 \mathrm{DAE}$ ), and a control without herbicide application. The grain sorghum (cv. AG-1040) was sown after the harvest of soybeans. The residual activity of these herbicides was determined by bioassay, using the same sorghum cultivars evaluated in the field during the period from 0 to 200days after application the treatments. The sorghum crop showed high sensitivity to residual activity of the herbicide sulfentrazone, diclosulam and imazethapyr dose of $0,100 \mathrm{~kg} \mathrm{ha}^{-1}$, even when grown after soybean harvest. Furthermore, the residual activity of sulfentrazone exceeded the range of assessment of bioassay, and more than 200 days.
\end{abstract}

Keywords: carryover, Sorghum bicolor, Glycine max, bioactivity.

\begin{abstract}
RESUMO - O sorgo granifero é uma espécie de destaque perante as culturas utilizadas em sucessão na região dos cerrados. No entanto, poucas informações referentes aos efeitos da atividade residual de herbicidas sobre essa cultura nessa região são conhecidas. O objetivo deste estudo foi avaliar a atividade residual de herbicidas utilizados no manejo de plantas daninhas na cultura da soja, bem como verificar seus efeitos sobre o sorgo granifero cultivado em sucessão. Para o experimento em campo, utilizou-se delineamento de blocos casualizados com quatro repetições. Oito tratamentos herbicidas foram avaliados: imazaquin $(0,161 \mathrm{~kg} \mathrm{ha-1})$, diclosulam $(0,035 \mathrm{~kg} \mathrm{ha-1})$, sulfentrazone $\left(0,600 \mathrm{~kg} \mathrm{ha}^{-1}\right)$ e flumioxazin $\left(0,05 \mathrm{~kg} \mathrm{ha}^{-1}\right)$, em aplicações realizadas em pré-emergência; e chlorimuron-

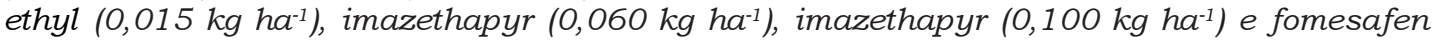
$\left(0,250 \mathrm{~kg} \mathrm{ha} \mathrm{h}^{-1}\right)$, aplicados em pós-emergência da cultura da soja (estádio V3, $\left.18 \mathrm{DAE}\right)$, além de uma testemunha sem a aplicação de herbicidas. O sorgo granífero (cv. AG-1040) foi semeado após a colheita da soja. A atividade residual desses herbicidas foi determinada por meio de bioensaio, utilizando-se o mesmo cultivar de sorgo avaliado em campo, durante o periodo de 0 a 200 dias após
\end{abstract}

1 Recebido para publicação em 3.4.2010 e na forma revisada em 17.12.2010.

2 Discente do Programa de Pós-Graduação em Agronomia, Universidade Estadual de Maringá - UEM/NAPD, Av. Colombo 5790, 87020-900 Maringá-PR, <halmeidadan@gmail.com>; ${ }^{3}$ Mestranda, Programa de Pós-Graduação em Agronomia, UEM; ${ }^{4}$ Professores da Faculdade de Agronomia, Universidade de Rio Verde - FESURV, Caixa Postal 104, 75901-970 Rio Verde-GO; ${ }^{5}$ Pesquisador, Embrapa Tabuleiros Costeiros, 49025-040 Aracaju-SE; ${ }^{6}$ Professor do Dep. de Agronomia, UEM/NAPD; ${ }^{7}$ Graduando em Agronomia, FESURV.

Planta Daninha, Viçosa-MG, v. 28, p.1087-1095, 2010. Número Especial 
a aplicação dos tratamentos. A cultura do sorgo apresentou elevada sensibilidade à atividade residual dos herbicidas sulfentrazone, diclosulam e imazethapyr na dose de $0,100 \mathrm{~kg} \mathrm{ha-1,} \mathrm{mesmo} \mathrm{quando}$ cultivada após a colheita da soja. Além disso, a atividade residual do herbicida sulfentrazone ultrapassou o intervalo de avaliação da espécie bioindicadora, sendo superior a 200 dias.

Palavras-chave: carryover, Sorghum bicolor, Glycine max, bioatividade

\section{INTRODUCTION}

The sorghum (Sorghum bicolor) is a summer species very used in India, United States and some countries in Africa, due its high nutritive value, and it has great utility for human (grains) and animal (fodders and grains) feeding (Dahlberg et al., 2004). In Brazil, sorghum has been highlighted mainly as second crop, being indicated as a viable alternative in corn replacement as succession crop, both for straw formation to the direct planting system and for grains and fodders production (Dan et al., 2010).

Due its great adaptation and diffusion in cerrados biome and in other producer regions, sorghum has been highlighted in the last few years, especially after the launching of hybrids with high productive potential, derived from the genetic improvement. Besides, the crop presents a good stubble production, which is an important option for the direct planting system (Cazetta et al., 2005). These facts together made possible that this crop could present an expressive economic value, achieving great appreciation in Brazilian cerrado.

Because of the rusticity and tolerance to the dry winter from Brazil's Mid-West, Southeast and part of the South regions, this crop has bigger farming expression in second crop, also known as "little crop", mainly in succession to the soybean agriculture. Despite the crop succession be considered as a reality in Brazil, almost nothing has been done to evaluate the effects of the residual activity of herbicides used in soybean agriculture on grain sorghum crop succession.

The herbicide persistence in environment represents his capacity in developing residual activity, preventing the development of a certain area weeds during a certain period. In the other side, herbicides with prolonged bioactivity could induce injuries to sensible plants cultivated in succession and even in crop rotation.

Herbicides with a bigger persistence in soil also present a higher environmental contamination risk, by leaching, volatilization or erosion. Several authors report the complexity of herbicides behavior in soil (Regitano et al., 2001; Oliveira Jr. et al., 2006; Inoue et al., 2008). In a similar way, the residual effects of herbicides applied to the soybean agriculture on succession crop have been reported in cotton (Grichar et al., 2004), corn (Ulbrich et al., 2005; Artuzi \& Contieiro, 2006), sunflower (Merotto Júnior \& Vidal, 2001; Brighenti et al., 2002) and sorghum crops (Silva et al., 1999) and horticultural plants (Szmigielski et al., 2009).

Nowadays, the use of soybean premature and super premature cycle, together with harvest anticipation techniques, is more and more common. These actions reduce the period of time between the herbicides in soybean agriculture application and the seeding of species in succeeding crop. For this reason, the risks of an occasional negative effect related to the residual activity of some herbicides on succession crops are increasing. The information survey about the safe breaks required in order to these products be dissipated in environment without affecting succession crops is essentially important for the economic and environmental maintenance of the second crop in Brazil. In this context, the aim of this work was evaluate the effects of the residual activity of herbicides used in soybean agriculture on grain sorghum crop succession in cerrado conditions.

\section{MATERIAL AND METHODS}

The experiments were conducted in Rio Verde-GO, located in the coordinates $17^{\circ} 48^{\prime} \mathrm{S}$, 
$55^{\circ} 55^{\prime} \mathrm{W}$ and the altitude of $760 \mathrm{~m}$, during the period of November, 2008 to July, 2009.

\section{Field experiment}

The experimental area soil is classified as Rhodic Hapludox of clayvey texture, with $510 \mathrm{~g} \mathrm{~kg}^{-1}$ of clay, $50 \mathrm{~g} \mathrm{~kg}^{-1}$ of silt, $440 \mathrm{~g} \mathrm{~kg}^{-1}$ of sand and $28,84 \mathrm{~g} \mathrm{~kg}^{-1}$ of MO and $\mathrm{pH}$ in water of 4,8 , in area under handled fallow conditions with $1,8 \mathrm{~kg} \mathrm{ha}^{-1}$ of glyphosate $+0,5 \mathrm{~kg} \mathrm{ha}^{-1}$ of 2,4-D, 15 days before the soybean seeding.

The grow of soybean M-soy 6101 was seeded in a spacing of $0,5 \mathrm{~m}$, in a mechanized form, resulting in a final population of

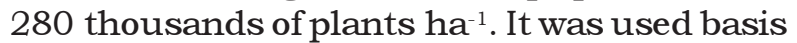
fertilizing with $80 \mathrm{~kg} \mathrm{ha}^{-1}$ of $\mathrm{P}_{2} \mathrm{O}_{5}$ (simple superphosphate), $20 \mathrm{~kg} \mathrm{ha}^{-1}$ of $\mathrm{K}_{2} \mathrm{O}$ (potassium chloride) and $30 \mathrm{~kg} \mathrm{ha}^{-1}$ of $\mathrm{K}_{2} \mathrm{O}$ in coverage to the 30 days after the emergency (DAE). The other crop treatments were developed according the crop normal recommendations.

The experiment was disposed in random blocks delineation, with four repetitions. The treatments corresponded to eight herbicide treatments: imazaquin $\left(0,161 \mathrm{~kg} \mathrm{ha}^{-1}\right)$, diclosulam $\left(0,035 \mathrm{~kg} \mathrm{ha}^{-1}\right)$, sulfentrazone $\left(0,600 \mathrm{~kg} \mathrm{ha}^{-1}\right)$ and flumioxazin $(0,050 \mathrm{~kg}$ ha $\left.{ }^{1}\right)$, in applications developed in pre-emergency, and chlorimuron-ethyl $\left(0,015 \mathrm{~kg} \mathrm{ha}^{-1}\right)$, imazethapyr $\left(0,060 \mathrm{~kg} \mathrm{ha}^{-1}\right)$, imazethapyr $\left(0,100 \mathrm{~kg} \mathrm{ha}^{-1}\right)$ and fomesafen $\left(0,250 \mathrm{~kg} \mathrm{ha}^{-1}\right)$, applied in post-emergency of soybean crop (estádio V3, $18 \mathrm{DAE}$ ), besides of witness without the herbicide application.

There were used parcels of $20 \mathrm{~m}^{2}(5 \times 4 \mathrm{~m})$, being the herbicide treatments application made through a pressurized backpack sprayer in $\mathrm{CO}_{2}$. The equipment was supplied by a $2,5 \mathrm{~m}$ bar, with six sprayer points type AI-110-02 $(0,5 \mathrm{~m}$ between the points), with service pressure of $2,5 \mathrm{kgf} \mathrm{cm}^{-2}$, providing a spray volume of $150 \mathrm{~L} \mathrm{ha}^{-1}$. The environmental conditions at the moment of the applications were the following: pre-emergency application (average temperature of $27,5{ }^{\circ} \mathrm{C}$, average UR of $79 \%$ and average wind speed of $6,1 \mathrm{~km} \mathrm{~h}^{-1}$ ); and post-emergency application (average temperature of $26,2{ }^{\circ} \mathrm{C}$, average UR of $82 \%$ and average wind speed of $2,4 \mathrm{~km} \mathrm{~h}^{-1}$ ).

The grain sorghum hybrid (cv. AG-1040) was seeded in a spacing of $0,5 \mathrm{~m}$, in a manual form, resulting in a final population of 140 thousands of plants ha $^{-1}$. The seeding occurred after the soybean harvest 115 days after the herbicides (DAA) application in preemergency and 97 DAA of the herbicides in post-emergency]. It was developed a basis fertilizing made of $200 \mathrm{~kg}$ of N-P-K, formula 0414-08, with posterior coverage fertilizing (40 kg ha-1 of nitrogen in form of ammonia sulphate, parceled equally in the stadiums V4 and V8). The weeds control in sorghum crop was made in a manual way, through de hoe. It was used supplementary irrigation to provide the best development of the crop.

After the sorghum emergency, there were made intoxication evaluations at 7,15 and 28DAE, using the percentage scale from (zero) to $100 \%$, in which 0 represents the symptoms absence and $100 \%$ the death of all the plants. It was also evaluated the plants stand through counting and, in four linear meters, the accrual of the air part from dry matter at 50 DAE. In order to make this happens, there were collected the plants present in a linear meter of each parcel, being this product dried in a stove with air circulation in $65^{\circ} \mathrm{C}$, until constant mass.

Besides, it was determined the plants height at 30 and $90 \mathrm{DAE}$, using the measuring tape, stipulating as basis the plant neck until the final extremity of spike. At the end of the crop cycle, it was obtained the grains revenue, determined through the thickness manual crop present in the $8 \mathrm{~m}^{2}$ parcel useful area, eliminating the borders; right after the harvest, the material was marked upon, weighed and the grains humidity corrected to $13 \%$.

The results related to the intoxication levels were submitted to a transformation $(\sqrt{ } \mathrm{x}+1)$ to follow the necessary principles to the variance analysis, which was developed with Sisvar statistical program. The results averages were compared by the Scott-Knott test to $5 \%$ of probability.

\section{Greenhouse experiment}

In order to evaluate the persistence from the herbicide residues used in the Field experiment, it was chosen by the bioindicator 
plants use (D'Antonino et al., 2009). In the greenhouse, there were conducted two experiments in a completely randomized design, with five repetitions, in a factorial scheme $5 \times 6$, represented by the treatments from each application mode (pre and postemergency), which were previously described, being the soil samples collected in six different periods $(0,35,70,105,140$ and 200 days after the application).

The soil composed samples were removed from $0-15 \mathrm{~cm}$ of depth in each parcel treated in field. To compose each sample, there were made 20 subsamples by treatment, which were mixed and homogenized. These composed samples were placed in plastic vases with capacity of $1 \mathrm{dm}^{-3}$ and packed in greenhouse, for the bioassay development.

The grain sorghum (cv. AG-1040) was used as a bio-indicator species, being seeded, in each experimental unit, three seeds, in an average depth of $1,5 \mathrm{~cm}$. During this period, the vases received daily irrigations intending the great growth of indicator plants. 25 days after the seeding, the plants air part was cut, continuing to the material drying in a forced ventilation stove in $72{ }^{\circ} \mathrm{C}$ until the constant mass, to the dry matter determination.

In order to eliminate the environment influence in the bioassays conduction periods, the material data were transformed in percentage values in respect of the witness treatment, adopting to each time a referential value of $100 \%$, being submitted, next, to the variance analysis.

In all the experiments, the results were submitted to the transformation $(\sqrt{ } \mathrm{x}+1)$ in order to attend the necessary principles to the variance analysis, which was developed with Sisvar statistical program. There were adjusted regression polynomial models to the variables that presented significance $(p \geq 0,05)$, using subsequently the Sigma Plot program, 10.0 version, to the regression curves confection.

\section{RESULTS AND DISCUSSION}

\section{Field experiment}

In Table 1 are presented the intoxication results obtained in evaluations from 7,15 and 28 days after the sorghum crop emergency (DAE). It is possible to observe that flumioxazin residues in soil provided the lowest levels of intoxication during the whole evaluation break. However, sulfentrazone residues caused a little clorose on the sorghum plants at $7 \mathrm{DAE}$. These symptoms progressed to the younger leaves empurple and necrosis at 15 DAE $(28,7 \%$ of intoxication), typicals of injuries caused by the inhibitor herbicides from PROTOX. Similar results were observed by Blanco \& Velini (2005) in the corn agriculture crop succession to soybean, after $1,2 \mathrm{~kg} \mathrm{ha}^{-1}$ application of sulfentrazone in medium textured soil. The visual effects

Table 1 - Intoxication in sorghum plants succession cultivated to the soybean crop in areas that received different herbicides with soil residual activity. Rio Verde-GO. 2008/2009

\begin{tabular}{|c|c|c|c|c|c|}
\hline \multirow{2}{*}{ Treatment } & \multirow{2}{*}{$\begin{array}{c}\text { Dose } \\
\left(\mathrm{kg} \text { de i.a. } \mathrm{ha}^{-1}\right)\end{array}$} & \multirow{2}{*}{ Mode } & \multicolumn{3}{|c|}{ Intoxication (\%) } \\
\hline & & & $7 \mathrm{DAE}^{*}$ & $15 \mathrm{DAE}$ & $28 \mathrm{DAE}$ \\
\hline Witness & - & - & $0.0 \mathrm{c}$ & $0.0 \mathrm{e}$ & $0.0 \mathrm{~d}$ \\
\hline Imazaquin & 0.161 & Pré & $12.0 \mathrm{a}$ & $9.0 \mathrm{~d}$ & $2.1 \mathrm{c}$ \\
\hline Diclosulam & 0.035 & Pré & $12.2 \mathrm{a}$ & $7.2 \mathrm{~d}$ & $6.3 \mathrm{~b}$ \\
\hline Sulfentrazone & 0.600 & Pré & $10.0 \mathrm{a}$ & $28.7 \mathrm{a}$ & $15.3 \mathrm{a}$ \\
\hline Flumioxazin & 0.050 & Pré & $0.0 \mathrm{c}$ & $0.0 \mathrm{e}$ & $0.0 \mathrm{~d}$ \\
\hline Chlorimuron-ethyl & 0.015 & Pós & $1.5 \mathrm{c}$ & $0.0 \mathrm{e}$ & $0.0 \mathrm{~d}$ \\
\hline Imazethapyr & 0.060 & Pós & $5.1 \mathrm{~b}$ & $7.7 \mathrm{~d}$ & $0.0 \mathrm{~d}$ \\
\hline Imazethapyr & 0.100 & Pós & $9.0 \mathrm{a}$ & $13.0 \mathrm{c}$ & $8.1 \mathrm{~b}$ \\
\hline Fomesafen & 0.250 & Pós & $6.7 \mathrm{~b}$ & $16.2 \mathrm{~b}$ & $3.2 \mathrm{c}$ \\
\hline Standart error & - & & 0.94 & 0.92 & 0.84 \\
\hline $\mathrm{CV} \%$ & - & & 9.96 & 11.61 & 8.32 \\
\hline
\end{tabular}

Averages of treatments followed by the same letter do not differ by the Scott-Knott test $p \geq 0,05 . *$ DAE: days after the emergency. 
provoked by the sulfentrazone action still were noticed at $28 \mathrm{DAE}$, but in a lower intensity, indicating a slight recovery of the species.

From the inhibitors herbicides of the acetolactate synthase enzyme (ALS), the residual activity of diclosulam, imazaquin and imazethapyr presented a higher intoxication potential in sorghum plants (Table 1). It was observed, after these herbicides application, internerval chlorosis followed by small stretch marks. Similar symptomatology was observed by Ulbrich et al. (2005) and Artuzi \& Contiero (2006), when evaluating the imidazolinonas effects in corn crop. These injuries were verified during the whole evaluation break, being this effect more intensified in soil with imazethapyr $\left(0,100 \mathrm{~kg} \mathrm{ha}^{-1}\right)$ and diclosulam $\left(0,035 \mathrm{~kg} \mathrm{ha}^{-1}\right)$ residues, at $28 \mathrm{DAE}$. However, the herbicide chlorimuron-ethyl application did not provoke intoxication symptoms in sorghum agriculture crop succession to soybean.

Though it had been observed intoxication symptoms in sorghum plants, no one herbicide treatment promoted the reduction of the crop plants population (non presented data). However, the residual activity from the diclosulam, sulfentrazone and imazethapyr $\left(0,100 \mathrm{~kg} \mathrm{ha}^{-1}\right)$ herbicides was enough to cause reductions in the plants height at $30 \mathrm{DAE}$ (Table 2). These effects were confirmed at $\mathrm{DAE}$, in particular for sulfentrazone, whose residual activity was enough to reduce the height of sorghum plants in $17 \%$. It is important to emphasize that the plants height is a preponderant factor in the grains harvest process, once that in cerrados region this species is mechanically collected.

When analyzing the accrual percentages of dry matter in air part (Table 3), it is verified that the biggest reductions were observed in the parcels that received sulfentrazone. Even when seeded at 115 DAA, sorghum had reduction of $52,3 \%$ in the accrual of dry matter in air part of plants, making clear the great sensibility from the species to this herbicide. Szmigielski et al. (2009) observed negative effects of this herbicide in beetroot plants during a period higher than 302 days, demonstrating the necessity of a bigger safe break between the sulfentrazone application and the seeding of this crop. Similar results were observed by Blanco \& Velini (2005) in corn agriculture crop succession to soybean, after the $0,6 \mathrm{~kg} \mathrm{ha}^{-1}$ sulfentrazone application.

The reduction in dry matter in air part of sorghum plants also was observed in soils with other herbicides residues. Imazaquin redidues caused reduction of $9,34 \%$ in this parameter. About the diclosulam and imazethapyr $\left(0,100 \mathrm{~kg} \mathrm{ha}^{-1}\right)$, the negative effect was of $9,61 \%$ and $12,4 \%$, respectively (Table 3 ). Ulbrich et al. (1998) did not verify negative effects about the dry matter in corn plants seeded 120 DAA, after the $120 \mathrm{~g} \mathrm{ha}^{-1}$ of imazaquin use.

Table 2 - Sorghum plants height succession cultivated to the soybean crop in areas that received different herbicides with soil residual activity. Rio Verde-GO. 2008/2009

\begin{tabular}{|c|c|c|c|c|}
\hline \multirow{2}{*}{ Treatment } & \multirow{2}{*}{$\begin{array}{c}\text { Dose } \\
\left(\mathrm{kg} \text { de i.a. } \mathrm{ha}^{-1}\right)\end{array}$} & \multirow{2}{*}{ Mode } & \multicolumn{2}{|c|}{ Plants height (m) } \\
\hline & & & $30 \mathrm{DAE}^{*}$ & $90 \mathrm{DAE}$ \\
\hline Witness & - & - & $10.1 \mathrm{a}$ & $1.35 \mathrm{a}$ \\
\hline Imazaquin & 0.161 & Pré & $10.5 \mathrm{a}$ & $1.25 \mathrm{~b}$ \\
\hline Diclosulam & 0.035 & Pré & $8.7 \mathrm{~b}$ & $1.24 \mathrm{~b}$ \\
\hline Sulfentrazone & 0.600 & Pré & $6.1 \mathrm{c}$ & $1.12 \mathrm{c}$ \\
\hline Flumioxazin & 0.050 & Pré & $10.4 \mathrm{a}$ & $1.34 \mathrm{a}$ \\
\hline Chlorimuron-ethyl & 0.015 & Pós & $10.4 \mathrm{a}$ & $1.34 \mathrm{a}$ \\
\hline Imazethapyr & 0.060 & Pós & $10.7 \mathrm{a}$ & $1.34 \mathrm{a}$ \\
\hline Imazethapyr & 0.100 & Pós & $6.7 \mathrm{c}$ & $1.25 \mathrm{~b}$ \\
\hline Fomesafen & 0.250 & Pós & $9.4 \mathrm{a}$ & $1.33 \mathrm{a}$ \\
\hline Standart error & - & & 0.289 & 0.018 \\
\hline $\mathrm{CV} \%$ & - & & 8.55 & 7.91 \\
\hline
\end{tabular}

Averages of treatments followed by the same letter do not differ by the Scott-Knott test $p \geq 0,05 . *$ DAE: days after the emergency. 
Table 3 - Reduction of the dry matter in air part (MSPA), evaluated at 50 days after the crop emergency, and revenue in the sorghum crop grains succession cultivated to the soybean, in areas that received different herbicides with soil residual activity. Rio Verde-GO. 2008/2009

\begin{tabular}{|c|c|c|c|c|}
\hline Treatment & $\begin{array}{c}\text { Dose } \\
\left(\mathrm{kg} \text { de i.a. } \mathrm{ha}^{-1}\right)\end{array}$ & Mode & $\begin{array}{c}\text { MSPA } \\
(\%)\end{array}$ & $\begin{array}{l}\text { Revenue } \\
\left(\mathrm{kg} \mathrm{ha}^{-1}\right)\end{array}$ \\
\hline Witness & - & - & $0.00 \mathrm{c}$ & $2,354 \mathrm{a}$ \\
\hline Imazaquin & 0,161 & Pré & $9.34 \mathrm{~b}$ & $2,263 \mathrm{a}$ \\
\hline Diclosulam & 0,035 & Pré & $9.61 \mathrm{~b}$ & $2,020 \mathrm{~b}$ \\
\hline Sulfentrazone & 0,600 & Pré & $52.35 \mathrm{a}$ & $1,431 \mathrm{c}$ \\
\hline Flumioxazin & 0,050 & Pré & $0.44 \mathrm{c}$ & $2,443 \mathrm{a}$ \\
\hline Chlorimuron-ethyl & 0,015 & Pós & $1.92 \mathrm{c}$ & $2,335 \mathrm{a}$ \\
\hline Imazethapyr & 0,060 & Pós & $2.46 \mathrm{c}$ & $2,322 \mathrm{a}$ \\
\hline Imazethapyr & 0,100 & Pós & $12.48 \mathrm{~b}$ & $2,094 \mathrm{~b}$ \\
\hline Fomesafen & 0,250 & Pós & $3.43 \mathrm{c}$ & $2,221 \mathrm{a}$ \\
\hline Standart error & - & & 1.89 & 69.93 \\
\hline $\mathrm{CV} \%$ & - & & 16.98 & 7.98 \\
\hline
\end{tabular}

Averages of treatments followed by the same letter do not differ by the Scott-Knott test $p \geq 0,05 . *$ DAE: days after the emergency.

The effects created by the sulfentrazone action on the photoassimilated accrual directly reverberated in sorghum crop revenue. The reduction caused by this treatment on the grains production almost reached $1.000 \mathrm{~kg}$ ha (Table 3). Tough residues in soil of imazaquin, diclosulam and imazethapyr $\left(0,100 \mathrm{~kg} \mathrm{ha}^{-1}\right)$ had also provided damages in the accrual of dry matter in sorghum plants air part, only diclosulam and imazethapyr $\left(0,100 \mathrm{~kg} \mathrm{ha}^{-1}\right)$ presented negative effects on the grains revenue. These effects were less drastic relating to the one observed after sulfentrazone application.

Soil residues of fomesafen, flumioxazin, chlorimuron-ethyl and imazethapyr $\left(0,060 \mathrm{~kg} \mathrm{ha}^{-1}\right)$ applied in soybean did not presented negative effects on the grains revenue in sorghum crop succession.

\section{Greenhouse experiment}

In Figure 1 are presented the average percentages of the reduction in the accrual of dry matter in sorghum plants air part used as a bioindicator plant. Considering the percentage of dry matter in sorghum plants air part reduction, it is verified, in all the situations, a less material reduction during the time after the application of evaluated herbicides. It is observed a bigger sensibility of the bioindicator species to the sulfentrazone herbicide. Its persistence in soil could be observed during a period higher than 200DAA, when it still provided about $9,1 \%$ of reduction on dry matter in the air part. Evaluating the sulfentrazone herbicide behavior in soil, Szmigielski et al. (2009) observed that this herbicide presents a high bioactivity in soils with low tenor of organic matter and clay, where its residual activity could overcome 302 days, fact also observed by Blanco \& Velini (2005). To Ohmes $\&$ Mueller (2007), the sulfentrazone sorption is more intense in clayvey soils.

The residual activity from the imazaquin and diclosulam herbicides also presented suppression potential on sorghum plants (Figure 1). The two products caused growth reduction, with accented chlorosis in the younger leaves. For both herbicides, the effects in time zero were more intense, reducing if had happened break time increase between the application and the bioindicator species seeding. Sorghum presented sensibility to imazaquin during approximately 140 DAA $(2,3 \%)$, from where practically did not has anymore reduction in air part matter (Figure 1), although it has been observed in the field experiment that this herbicide bioactivity did not modify the grains crop revenue. Ulbrich et al. (1998) observed negative effects from the $240 \mathrm{~g} \mathrm{ha}^{-1}$ of imazaquin use in corn and cucumber plants crop until 133 DAA. 


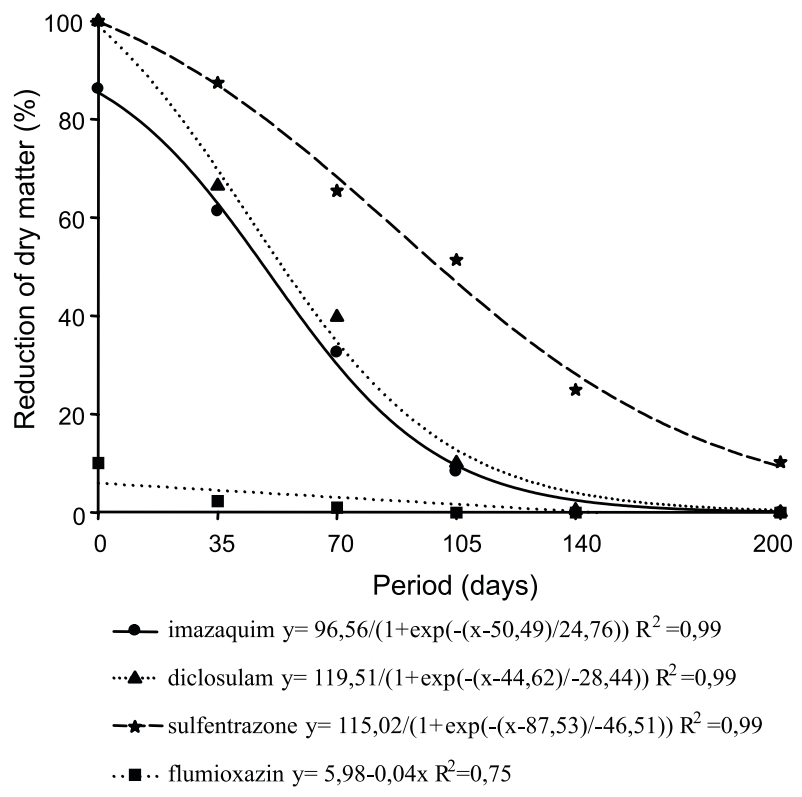

Figure 1 - Reduction in the accrual of dry matter in sorghum plants air part cultivated in collected soil from areas cultivated with soybean, which received the pre-emergency application of the herbicides imazaquin, diclosulam, sulfentrazone and flumioxazin

The diclosulam effects were slightly higher than the ones observed in imazaquin, despite his residual activity be observed in a similar way to this herbicide (Figure 1). Despite of low, this bioactivity was enough to reduce the crop grains revenue in the Field experiment. According to Lavorenti et al. (2003), diclosulam is an herbicide of intermediary residual activity, being his half-life $\left(t_{1 / 2}\right)$ of 67 days in areas cultivated in direct planting system and 87 days in soils cultivated in conventional system. Despite these results, the $33,6 \mathrm{~g} \mathrm{ha}^{1}$ dose of diclosulam was enough to reduce the sunflower crop stand seeded 90 days after its application in soybean (Brighenti et al., 2002).

Investigating the flumioxazin herbicide effects on the bioindicator species (Figure 1), is possible to observe that sorghum presented low sensibility to this herbicide even when cultivated in smaller time breaks, corroborating the results found in field. According to Ferrell et al. (2004), flumioxazin is adsorbed by soil colloids and mainly by the organic matter, because of it does not present dissociation in water. Besides, it shows quick dissipation in soil, in other words, his half-life could vary from 10 to 25 days, agreeing with the results observed in this study.
In the herbicides applied in soybean post-emergency, grain sorghum presented enough intoxication symptoms to reduce the accrual of dry matter in air part of plants cultivated in the treatments with imazethapyr (the both doses) and the fomesafen in collected samples right after the herbicides application (O DAA) (Figure 2). These effects were observed in lower intensity in the growing with bigger time breaks between the herbicides application and the samples swab for the bioassay development.

Considering the percentage of reduction in air part of dry matter, chlorimuron-ethyl showed less persistence when compared to the other herbicides, being observed bioactivity in time breaks under than 105 DAA. According to Rodrigues \& Almeida (2005), this composed presents moderate adsorption and leaching and half-life of 7,5 weeks.

Another herbicide inhibitor from the acetolactate synthase enzyme (ALS) that presented the consistent bioactive effect was the imazethapyr. The residual activity of this herbicide induced intense suppression to the sorghum plants. It was possible to verify growth reduction with accented chlorosis in

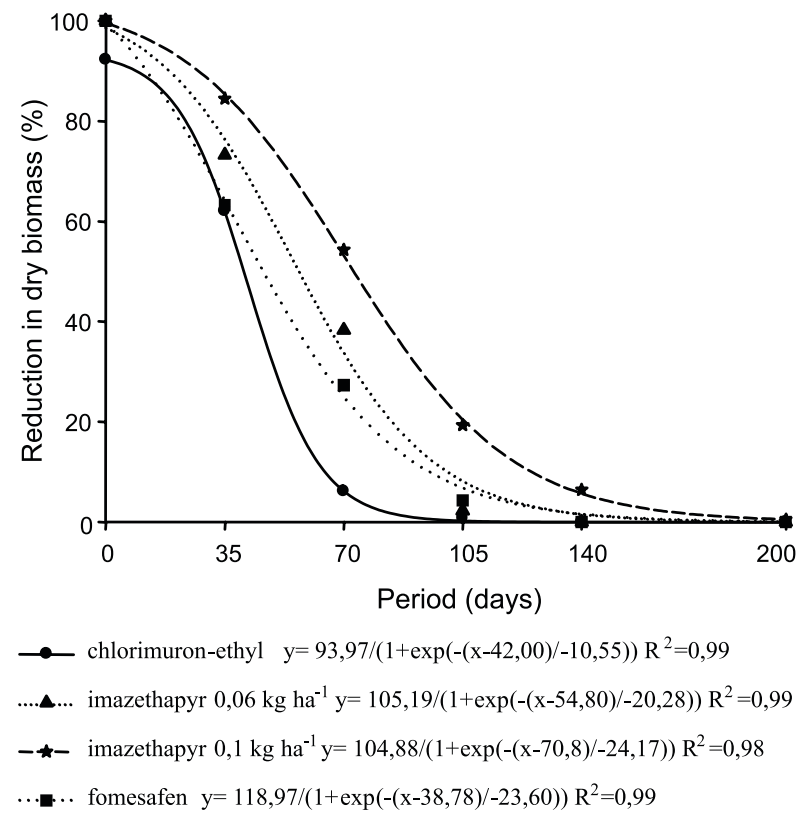

Figure 2 - Reduction in the accrual of dry matter in sorghum plants air part cultivated in collected soil from areas cultivated with soybean, which received the post-emergency application of the herbicides chlorimuron-ethyl, imazethapyr $\left(0,060 \mathrm{~kg} \mathrm{ha}^{-1}\right)$, imazethapyr $\left(0,100 \mathrm{~kg} \mathrm{ha}^{-1}\right)$ and fomesafen. 
the younger leaves. These effects were presented in bigger intensity in time zero, being inversely proportional to the time break between the application and the bioindicator species seeding. A low effect on the accumulated dry matter was obtained with imazethapyr applied in the smaller dose $\left(0,060 \mathrm{~kg} \mathrm{ha}^{-1}\right)$ (Figure 2). However, this bioactivity, in turn, was not enough to cause damages in the revenue of sorghum crop grains cultivated at 115 DAA (Table 3 ). In the commercial dose of imazethapyr $\left(0,100 \mathrm{~kg} \mathrm{ha}^{-1}\right)$ applied in post-emergency soybean agriculture, the effects were more rigids and continued during a bigger period of time when compared to the lower dose (Figure 2). Reductions in the dry matter in sorghum plants after the imazethapyr application $\left(0,100 \mathrm{~kg} \mathrm{ha}^{-1}\right)$ were perceptible in a period slightly higher than 140 DAA. The bioactivity from this herbicide treatment provided slight chlorosis, followed by reductions in the plants heights and in the accrual of dry matter in air part. Bioactivity negative effects also were observed in field growing. Silva et al. (1999) did not obtain significant reductions in the revenue of sorghum and corn crop grains seeded at 150 DAA of imazethapyr $\left(0,100 \mathrm{~kg} \mathrm{ha}^{-1}\right)$. Ulbrich et al. (1998) and Artuzi \& Contieiro (2006), report that imazethapyr residual activity was not enough to reduce the revenue in the corn crop grains seeded after 90 DAA.

The bigger bioactivity of this herbicide could be explained by the low soil $\mathrm{pH}$ used in the experiment $(4,8)$. According to Bresnaham et al. (2000), the imazethapyr sorption increases with the $\mathrm{pH}$ reduction, causing a higher toxicity in susceptible crops, because of his bigger soil sorption.

Fomesafen was another herbicide that presented high starting activity on the bioindicator species (Figure 2). As well as in the other treatments, his residual activity was reducing with the time break increase between the application and the soil samples swab. The fomesafen residual activity about the sorghum was observed in 140 DAA approximately. However, this bioactivity, in turn, was not enough to cause damages in the revenue of sorghum crop cultivated at 115 DAA (Table 3), showing that this species presented a higher tolerance to the residual effects from the herbicide. Monitoring fomesafen residual effect in the beans-corn succession in the cerrado region, Cobucci et al. (1997) observed that his half-life continued during 100 days approximately, in other words, very similar values to the ones found in this work. However, the authors report that there were found residues of this herbicide 212 DAA, but without activity to influence the corn crop grains revenue.

The sorghum crop showed high sensibility to the residual activity of the herbicides sulfentrazone, diclosulam and imazethapyr $\left(0,100 \mathrm{~kg} \mathrm{ha}^{-1}\right)$, even when cultivated after the soybean harvest. Besides, sulfentrazone residual activity was detected during all the evaluation break of the bioindicator species. From all the herbicides used in soybean post-emergency, only imazethapyr in the $0,100 \mathrm{~kg} \mathrm{ha}^{-1}$ dose presented significant potential of causing negative effects in sorghum grains revenue.

\section{LITERATURA CITADA}

ARTUZI, J. P.; CONTIERO, R. L. Herbicidas aplicados na soja e produtividade do milho em sucessão. Pesq. Agropec. Bras., v. 41, n. 7, p. 1119-1123, 2006.

BLANCO, F. M. G.; VELINI, E. D. Persistência do herbicida sulfentrazone em solo cultivado com soja e seu efeito em culturas sucedâneas. Planta Daninha, v. 23, n. 4, p. 693-700, 2005.

BRESNAHAM, G. A. et al. Influence of soil pH-sorption interactions on imazethapyr carry-over. Weed Sci., v. 48, p. 1929-1934, 2000 .

BRIGHENTI, A. M. et al. Persistência e fitotoxicidade do herbicida atrazine aplicado na cultura do milho sobre a cultura do girassol em sucessão. Pesq. Agropec. Bras., v. 20, n. 1, p. 291-297, 2002.

CAZETTA, D. A. et al. Composição, produção de matéria seca e cobertura do solo em cultivo exclusivo e consorciado de milheto e crotalária. Acta Sci., v. 27, n. 2, p. 575-580, 2005.

COBUCCI, T.; SILVA, J. B.; PRATES, H. T. Carryover effect of fomesafen, applied on edible bean, on sucessional maize. Planta Daninha, v. 15, n. 2, p. 180-189, 1997.

DAHLBERG, J. A. et al. Development of a sorghum core collection: refinement and evaluation of a subset from Sudan Econ. Bot., v. 58, n. 4, p. 556-567, 2004.

D'ANTONINO, L. et al. Efeitos de culturas na persistência de herbicidas auxínicos no solo. Planta Daninha, v. 27, n. 2, p. 371-378, 2009. 
DAN, H. A. et al. Tolerância do sorgo granífero ao herbicida tembotrione. Planta Daninha, v. 28, n. 3. p. 615-620, 2010.

FERRELL, J. A. et al. Sorption and desorption of flumioxazin to soil, clay minerals and ion-exchange resin. Pest Manag. Sci., v. 61, n. 1, p. 40-46, 2004.

GRICHAR, W. J. et al. Cotton response to Imazapic and Imazethapyr residues. Following peanut. Texas J. Agric. Nat. Res., v. 17, n. 1, p. 1-8, 2004.

INOUE, M.H. et al. Lixiviação e degradação de diuron em dois solos de textura contrastante. Acta Scient., v. 30, n. 1, p. 631-638, 2008.

LAVORENTI, A. et al. Comportamento do diclosulam em amostras de um latossolo vermelho distroférrico sob plantio direto e convencional. R. Bras. C. Solo, v. 27, n. 1, p. 183-190, 2003.

MEROTTO JÚNIOR, A.; VIDAL, R. A. Herbicidas inibidores de Protox. In: VIDAL, R. A.; MEROTTO JÚNIOR, A. (Eds.). Herbicidologia. Porto Alegre: Evangraf, 2001. $152 \mathrm{p}$.

OHMES, G. A.; MUELLER, T. C. Sulfentrazone adsorption and mobility in surface soil of the southern United States.

Weed Technol., v. 21, n. 1, p. 796-800, 2007.
OLIVEIRA JR., R. S. et al. Influência do período de restrição hídrica na atividade residual de isoxaflutole no solo. Planta Daninha, v. 24, n. 4, p. 733-740, 2006

REGITANO, J. B. et al. Transformation pathways of 14Cchlorothalonil in tropical soils. Arch. Environ. Contam. Toxicol., v. 40, n. 3, p. 295-302, 2001.

RODRIGUES, B. N.; ALMEIDA, F. S. Guia de herbicidas. 5.ed. Londrina: Grafmarke, 2005. 591 p.

SILVA, A. A. et al. Efeito residual no solo dos herbicidas imazamox e imazethapyr para as culturas de milho e sorgo. Planta Daninha, v. 17, n. 3, p. 345-354, 1999.

SZMIGIELSKI, A. M. et al. Development of a laboratory bioassay and effect of soil properties on sulfentrazone phytotoxicity in soil. Weed Technol., v. 23, p. 486-491, 2009.

ULBRICH, A. V.; RODRIGUES, B. N.; LIMA, J. Efeito residual dos herbicidas imazaquin e imazethapyr, aplicados na soja, sobre o milho safrinha. Planta Daninha, v. 16, n. 1, p. $137-147,1998$.

ULBRICH, A. V.; SOUZA, J. R. P.; SHANER, D. E. Persistence and carryover effect of imazapic and imazapyr in Brazilian cropping systems. Weed Technol., v. 19, p. 986-991, 2005. 